\title{
POTASSIUM CONTENT OF PUERTO RICAN SOILS AS RELATED TO SUGARCANE GROWING ${ }^{1}$
}

\author{
By Juan A. Bonnet ${ }^{2}$ \\ INTRODUCTION
}

Potassium may occur in soils in one or more of the following forms: As a constituent of some primary minerals such as feldspars and micas; associated with a secondary clay mineral as exchangeable potassium; as nonexchangeable potassium, such as within the clay-mineral lattice; and as water-soluble potassium salts.

The primary potassium-bearing minerals that may be found in soils are orthoclase, a potash feldspar, $\mathrm{KAlSi}_{3} \mathrm{O}_{8}$; microline, resembling orthoclase but differing in molecular structure and in optical characteristics; muscovite, a fairly stable mica, $\mathrm{KH}_{2} \mathrm{Al}_{3} \mathrm{Si}_{3} \mathrm{O}_{12}$; glauconite, a green granular silicate of potassium and iron closely related to the micas; and biotite, a potassiummagnesium-iron-aluminum silicate, a mica not very resistant to decomposition.

Sericite, or secondary muscovite, a compact or fibrous mica-bearing potassium derived by the conversion or sericitization, of orthoclase feldspar, is also found in some soils.

The potassium in the feldspars and mica minerals is distributed in the coarser sand and silt fractions of the soil.

The range of potassium content varies from about 0.15 percent $\mathrm{K}_{2} \mathrm{O}$ in sands to over 4 percent in clays. The clay mineral has the power to fix the potassium cation from the soluble salts in the run-off and drainage waters.

When soluble potash salts are applied to soils, the potassium may be retained in either or both of two forms; namely, the readily available or exchangeable form and the difficultly available or fixed form. The nature of potash fixation have been studied by several investigators and different explanations have been offered. Volk $(9)^{3}$ has suggested that $\mathrm{K}$ is fixed by muscovite or reacts with silicates to form difficultly soluble muscovite. Truog and Jones (8) have found that alternate wetting and drying hasten the fixation of potassium.

Stewart and Volk (7) said that the variable capacity of different soils to release potassium from the nonexchangeable form for plant consumption

${ }^{1}$ Paper prepared for the Eighth Congress of the International Society of Sugarcane Technologists at Barbados, B.W.I., in April 1953.

${ }^{2}$ Head, Soils Department, Agricultural Experiment Station, University of Puerto Rico, Río Piedras, P. R.

${ }^{3}$ Numbers in parentheses refer to Literature Cited pp. 193-4. 
appeared to be a dominant factor in the nutrition of plants, and that the magnitude of this factor was difficult to measure with chemical soil tests.

Potassium fertilizers are currently used at excess levels in the sugarcane fields of Puerto Rico. There are no potash deposits here and high-priced potash bearing materials are imported. A total of 43,971 tons of potash fertilizer salts ${ }^{4}$ at a total cost of $\$ 2,863,126$ was imported in fiscal year 1951-52. The N-P-K fertilizer formulae sold for sugarcane in Puerto Rico vary from 5 to 20 percent of $\mathrm{K}_{2} \mathrm{O}$ and potash is applied at rates varying from 70 to 216 pounds $\mathrm{K}_{2} \mathrm{O}$ to the acre. It is estimated that about $\$ 600,000$ is wasted annually on potash fertilizers applied excessively to sugarcane fields in Puerto Rico.

\section{OBJECTIVE}

The objective of this paper is to present data which show that chemical methods are not always reliable when used to determine the potash that plants absorb from the soil.

\section{FINDINGS}

\section{Potash-Bearing Minerals of Puerto Rico Soils}

Muscovite, a mica primary mineral bearing potassium, was identified (1) in the specific gravity groups: Greater than 2.98, 2.70-2.98, 2.50-2.70, and less than 2.50, of the silt fraction of Catalina clay, a Low Humic Latosol from Puerto Rico. Muscovite was relatively scarce in the first two specific gravity groups, abundant in the third, and present in traces in the last. Small quantities of sericite, a secondary muscovite, were found in the specific gravity group, $2.70-2.98$. The primary orthoclase feldspar was absent.

Jeffries, Bonnet, and Abruña (4) reported the absence of micas, especially the common muscovite, in 42 soil profiles, including 118 soil samples of Puerto Rico studied. Traces only of orthoclase were found in the alluvial soils of the Coloso series in the humid area, and in the Juncos and Las Piedras series of the Gray Brown Podzolic group. The principal feldspars identified were those of the plagioclase series: Oligoclase, andesine, and traces of labradorite, all containing sodium and calcium in varying proportions.

\section{Potash Data on Puerto Rico Soils}

The data on total potash in Puerto Rico soils are limited to those published in the Soil Survey of Puerto Rico (5) for eight soil profiles including five Latosols and two Gray-Brown Podzolic soils reported in table 1.

440,795 tons of muriate of potash and 3,176 tons of sulfate of potash at $\$ 64.50$ and $\$ 73.00$ per ton, respectively. 
Bonnet (2) has reported that the mean available potash extracted by 1-percent citric acid from the surface soils of the soil series of the humid

TABle 1.-Total potash in 8 soil profiles of the Puerto Rico humid area

\begin{tabular}{|c|c|c|c|c|c|}
\hline Soil Group & Soil series & Horizon & Depth & Total $\mathrm{K}_{2} \mathrm{O}$ & $\mathrm{K}_{2} \mathrm{O}$ per acre \\
\hline \multirow{5}{*}{ Reddish Brown Lateritic } & \multirow{5}{*}{ Catalina } & & Inches & Percent & Pounds \\
\hline & & A & $0-18$ & 0.08 & 1,600 \\
\hline & & B & $18-28$ & .01 & 200 \\
\hline & & C1 & $28-68$ & .91 & 18,200 \\
\hline & & $\mathrm{C} 2$ & $68-88$ & .84 & 16,800 \\
\hline \multirow{4}{*}{ Do. } & \multirow{6}{*}{ Cialitos } & C3 & $88-125$ & .75 & 15,000 \\
\hline & & $\mathrm{A} 1$ & $0-6$ & .06 & 1,200 \\
\hline & & $\mathrm{A} 2$ & $6-12$ & .15 & 3,000 \\
\hline & & $\mathrm{B} 1$ & $12-24$ & .20 & 4,000 \\
\hline \multirow[t]{2}{*}{ - } & & $\mathrm{B} 2$ & $24-36$ & .16 & 3,200 \\
\hline & & $\mathrm{C}$ & $36-48$ & 1 & - \\
\hline \multirow[t]{4}{*}{ Yellowish Brown Lateritic } & \multirow[t]{4}{*}{ Coto } & A1 & $0-7$ & .18 & 3,600 \\
\hline & & B1 & $7-17$ & .15 & 3,000 \\
\hline & & $\mathrm{B} 2$ & $17-40$ & .23 & 4,600 \\
\hline & & $\mathrm{C}$ & $40-70$ & .19 & 3,800 \\
\hline \multirow[t]{5}{*}{ Do. } & \multirow[t]{5}{*}{ Matanzas } & A1 & $0-12$ & .23 & 4,600 \\
\hline & & $\mathrm{B} 1$ & $12-21$ & .16 & 3,200 \\
\hline & & $\mathrm{B} 2$ & $21-34$ & .23 & 4,600 \\
\hline & & $\mathrm{C} 1$ & $34-68$ & .21 & 4,200 \\
\hline & & $\mathrm{C}_{2}$ & $68+$ & .21 & 4,200 \\
\hline \multirow[t]{5}{*}{ Do. } & \multirow[t]{5}{*}{ Nipe } & A & $0-5$ & 0.9 & 1,800 \\
\hline & & $\mathrm{B} 1$ & $5-15$. & .02 & 400 \\
\hline & & $\mathrm{B} 2$ & $15-50$ & 1 & - \\
\hline & & C1 & 60 & 1 & - \\
\hline & & $\mathrm{C} 2$ & 144 & 1 & - \\
\hline \multirow[t]{4}{*}{ Gray Brown Podzolic } & \multirow[t]{4}{*}{ Fajardo } & A & $0-6$ & .18 & 3,600 \\
\hline & & B1 & $6-12$ & .42 & 8,400 \\
\hline & & $\mathrm{B} 2$ & $12-28$ & .49 & 9,800 \\
\hline & & $\mathrm{C}$ & $28-50$ & .60 & 12,000 \\
\hline \multirow[t]{3}{*}{ Do. } & \multirow[t]{3}{*}{ Yunes $^{2}$} & A & $0-6$ & .11 & 2,200 \\
\hline & & B & $6-9$ & .17 & 3,400 \\
\hline & & $\mathrm{C}$ & $9-30$ & .15 & 3,000 \\
\hline \multirow[t]{3}{*}{ Do. } & \multirow[t]{3}{*}{ do. ${ }^{3}$} & A & $0-4$ & .65 & 13,000 \\
\hline & & B & $4-14$ & .42 & 8,400 \\
\hline & & $\mathrm{C}$ & $14-28$ & .62 & 12,400 \\
\hline
\end{tabular}

1 Trace.

${ }^{2}$ Clay.

${ }^{3}$ Silt loam.

area of Puerto Rico was $0.020 \pm 0.0015$ percent of $\mathrm{K}_{2} \mathrm{O}$. That of the arid area, with a mean annual rainfall below 55 inches, was $0.023 \pm 0.0017$ percent of $\mathrm{K}_{2} \mathrm{O}$. There was no significant difference between those mean 
TABLE 2.-Exchangeable potash extracted with 1-percent citric acid from samples in certain soil groups of Puerto Rico

\begin{tabular}{|c|c|c|c|}
\hline Sample No. & Soil group & Range of $\mathrm{K}_{2} \mathrm{O}$ per acre & $\begin{array}{c}\text { Mean } \mathrm{K}_{2} \mathrm{O} \\
\text { per acre }\end{array}$ \\
\hline & & Pounds & Pounds \\
\hline 6 & Ground Water Podzol & $100-420$ & 240 \\
\hline 31 & Reddish Brown Lateritic & $80-620$ & 300 \\
\hline 10 & Yellowish Brown Lateritic & $100-1,060$ & 340 \\
\hline 24 & Gray Brown Podzolic & $80-760$ & 340 \\
\hline 62 & Alluvial & $120-1,600$ & 340 \\
\hline 18 & Lithosols & $60-1,300$ & 360 \\
\hline 32 & Reddish Prairie & $120-1,060$ & 400 \\
\hline 13 & Chernozem & $180-760$ & 400 \\
\hline 14 & Planosol & $100-1,140$ & 440 \\
\hline 22 & Red and Yellow Podzolic & $100-1,080$ & 440 \\
\hline 14 & Rendzina & $100-1,200$ & 440 \\
\hline 19 & Sands & $100-1,260$ & 440 \\
\hline 10 & Reddish Chestnut & $120-1,040$ & 460 \\
\hline 4 & Red Desert & $120-980$ & 560 \\
\hline 8 & Reddish Brown & $340-1,060$ & 600 \\
\hline 6 & Solonchak & $280-1,240$ & 660 \\
\hline 11 & Wiesenboden & $120-1,920$ & 680 \\
\hline 4 & Half-Bog & $220-1,620$ & 860 \\
\hline
\end{tabular}

TABLE 3.-Available potash extracted by sorghum in pot tests from certain Puerto Rico soil groups

\begin{tabular}{r|l|c|c}
\hline Sample No. & \multicolumn{1}{|c}{ Soil group } & Range of $\mathrm{K}_{2} \mathrm{O}$ per acre & $\begin{array}{c}\text { Mean } \mathrm{K}_{2} \mathrm{O} \\
\text { per acre }\end{array}$ \\
\cline { 2 - 3 } & & Pounds & Pounds \\
1 & Sands & 122 & 122 \\
2 & Planosol & $204-344$ & 274 \\
7 & Red and Yellow Podzolic & $234-598$ & 408 \\
12 & Alluvial & $158-547-1,572^{1}$ & 415 \\
1 & Yellowish Brown Lateritic & 421 & 421 \\
7 & Reddish Brown Lateritic & $276-884$ & 423 \\
2 & Bog & $360-640$ & 500 \\
7 & Reddish Prairie & $328-1,017$ & 546 \\
6 & Gray Brown Podzolic & $314-939$ & 678 \\
1 & Half-Bog & 684 & 684 \\
1 & Reddish Chestnut & 714 & 714 \\
4 & Lithosols & $125-2,961$ & 1,019 \\
3 & Rendzina & $520-1,727$ & 1,050 \\
1 & Chernozem & 1,496 & 1,496 \\
1 & Reddish Brown & 2,054 & 2,054 \\
\hline
\end{tabular}

${ }^{1}$ San Antón loam in the arid irrigated area. 
values. There was a significant positive correlation in the soil series of the humid area between the available potash and the organic matter of those

TABLE 4.-Mean available potash extracted by sorghum and by 1-percent citric acid from some Puerto Rican soil groups and series in which feldspars were present and clay minerals were identified

\begin{tabular}{|c|c|c|c|c|}
\hline \multirow{2}{*}{ Soil group } & \multirow{2}{*}{ Soil series } & \multicolumn{2}{|c|}{$\mathrm{K}_{2} \mathrm{O}$ per acre extracted by -} & \multirow{2}{*}{ Clay mineral } \\
\hline & & Sorghum & $\begin{array}{l}\text { 1-percent } \\
\text { citric acid }\end{array}$ & \\
\hline & & Pounds & Pounds & \\
\hline $\begin{array}{c}\text { Gray Brown Pod- } \\
\text { zolic. . . . . . . }\end{array}$ & Ciales & 939 & 280 & Kaolin, illite \\
\hline Do.............. & Humacao & - & 420 & Kaolin \\
\hline Do..$\cdots \cdots \cdots$ & Juncos ${ }^{1}$ & 820 & 200 & $\begin{array}{l}\text { Montmorillonite, } \\
\text { kaolin }\end{array}$ \\
\hline Do. . & Las Piedras ${ }^{1}$ & - & 120 & Kaolin, beidellite \\
\hline Do.. & Teja & - & 500 & Kaolin \\
\hline Do.............. & Utuado & 697 & 260 & Do. \\
\hline Reddish Brown & & & & \\
\hline Lateritic....... & Alonso & 436 & 380 & Do. \\
\hline Reddish Prairie... & Mabí & $449,1,017,505$ & 400 & $\begin{array}{l}\text { Kaolin, illite, } \\
\text { Beidellite }\end{array}$ \\
\hline Do... & Paso Seco & 542 & 660 & Kaolin, illite \\
\hline $\begin{array}{r}\text { Reddish } \quad \text { Chest- } \\
\text { nut............ }\end{array}$ & Fraternidad & - & 280 & $\begin{array}{l}\text { Beidellite (carbo- } \\
\text { nates) }\end{array}$ \\
\hline Reddish Brown... & Jácana & 2,054 & 420 & - \\
\hline Planosol........... & Santa Isabel & - & 700 & Kaolin-illite \\
\hline Wiesenboden..... & Guánica & - & 220 & Beidellite \\
\hline Alluvial ......... & Aguirre & - & 480 & Beidellite \\
\hline Do........ & Coloso ${ }^{1}$ & $363,278,493$ & 300 & Kaolin \\
\hline Do......... & San Antón & 1,572 & 380 & $\begin{array}{l}\text { Illite, kaolin, chlo- } \\
\text { rite, beidellite }\end{array}$ \\
\hline Do.. & Toa & 521,547 & 420 & Kaolin, beidellite \\
\hline Do.... & Viví & 213,158 & 240 & Kaolin \\
\hline Lithosols. . & Descalabrado & 850 & 200 & Illite \\
\hline Do...... & Múcara & $125,144,2,961$ & 360,840 & Beidellite \\
\hline Do... & Pandura & - & 220 & Kaolin, illite \\
\hline Mean .......... & & 747 & 376 & \\
\hline
\end{tabular}

${ }^{1}$ Soils wherein orthoclase feldspar was identified, together with plagioclase feldspars generally found in the other soils.

surface soils. No such correlation was found for the arid area. The range of values for the 117 soils analyzed is reported in table 2.

Capó (3) reported the contents of available potash, nitrogen, and phos- 
phorus of 56 Puerto Rican soil samples as determined in pot tests using dwarf sorghum, hegari varitey, as a crop index. The available potash data

TABLE 5.-Mean available potash extracted by sorghum and by 1-percent citric acid from some Puerto Rican soil groups and series from which feldspars were absent and in which clay minerals were identified

\begin{tabular}{|c|c|c|c|c|}
\hline \multirow{2}{*}{ - Soil group } & \multirow{2}{*}{ Soil series } & \multicolumn{2}{|c|}{$\mathrm{K}_{2} \mathrm{O}$ per acre extracted } & \multirow{2}{*}{ Clay mineral } \\
\hline & & Sorghum & $\begin{array}{l}\text { 1-percent } \\
\text { citric acid }\end{array}$ & \\
\hline & & Pounds & Pounds & \\
\hline $\begin{array}{r}\text { Red and Yellow Pod- } \\
\text { zolic................ }\end{array}$ & Cabo Rojo & 234 & - & $\begin{array}{l}\text { Beidellite, kaolin, } \\
\text { montmorillonite }\end{array}$ \\
\hline Do.. & Lares & 408 & 400 & Kaolin \\
\hline Do.. & Los Guineos & 570 & 220 & Do. \\
\hline Do............. & Moca & 329 & 480 & $\begin{array}{l}\text { Kaolin, montmoril- } \\
\text { lonite, illite }\end{array}$ \\
\hline $\begin{array}{c}\text { Reddish Brown Later- } \\
\text { itic.................. }\end{array}$ & Bayamón & 884 & 120,300 & Kaolin \\
\hline Do............... & Catalina & 353,400 & 300 & Do. \\
\hline Do............ & Cialitos & 276 & 240 & $\begin{array}{l}\text { Kaolin, traces of } \\
\text { illite }\end{array}$ \\
\hline Do... & Islote & 一 & 520 & Kaolin, illite \\
\hline Do............ & Maleza & 一 & 220 & Kaolin \\
\hline Do............. & Matanzas & - & 300 & Do. \\
\hline Do................... & Río Piedras & 296 & 300 & Do. \\
\hline $\begin{array}{c}\text { Yellowish Brown La- } \\
\text { teritic................ }\end{array}$ & Coto & 421 & 420 & Do. \\
\hline Laterite............. & Nipe & - & 720 & Do. \\
\hline Rendzina......... & Aguilita & 903 & 380 & Beidellite \\
\hline Do............. & Soller & - & 600 & Kaolin \\
\hline Planosol........... & Guayabo & - & 280 & \\
\hline Do............. & Sabana Seca & 204 & 220 & Do. \\
\hline Ground Water Podzol.... & Corozo & - & 200 & Do. \\
\hline Lithosol. ......... & Tanamá & 一 & 720 & Kaolin \\
\hline Mean... & & 440 & 365 & \\
\hline
\end{tabular}

or $b$ values are reported in table 3 as calculated by the Mitscherlich's equation:

$$
Y=A\left(1-R^{x+b}\right)
$$

The mean $R$ value ${ }^{5}$ calculated for $\mathrm{K}_{2} \mathrm{O}$ was $0.036 \pm 0.008$ with the nutrient concentration expressed in terms of grams per pot.

${ }_{5}^{5}$ The mean $R$ values calculated for $\mathrm{NH}_{3}$ and $\mathrm{P}_{2} \mathrm{O}_{5}$ were $0.095 \pm 0.015$, and 0.097 \pm 0.021 , respectively. 
The mean available potash in pounds per acre extracted by the sorghum and by 1-percent citric acid from some Puerto Rico soils in which feldspars were present or absent, is reported in tables 4 and 5, respectively. The clay minerals identified in those soils are also reported.

In soils in which feldspars were present, the mean available potash extracted by the sorghum and by 1-percent citric acid was equivalent to 747 and 376 pounds of $\mathrm{K}_{2} \mathrm{O}$ per acre, respectively. The sorghum extracted about twice as much potash. In soils from which feldspars were absent, the mean available potash extracted by the sorghum and by 1-percent citric acid was equivalent to 440 and 365 pounds of $\mathrm{K}_{2} \mathrm{O}$ per acre, respectively. The presence or absence of feldspars did not affect the mean potash extracted from the soils by 1-percent citric acid. The potash extracted by the acid was exchangeable potash. The potash extracted generally from the soil by the sorghum, when feldspars were absent, was also exchangeable potash; but when feldspars were present, it was exchangeable potash plus available potash from other sources such as feldspars and micas.

The feldspars identified in those soils were generally of the plagioclase series, except for traces of orthoclase identified in the Coloso, Juncos, and Las Piedras, series (table 4). Since plagioclase feldspars should contain no potassium and since muscovite, another common potash mineral, was generally absent, except in Catalina clay (1), the source of the available potash extracted by the sorghum plant is of interest. The plagioclase feldspar minerals might constitute a source of potash since, according to Winchell (10), the albite molecule forms three crystal phases with sanidine, adularia, and microcline, all of which are potash feldspars of the general formula, $\mathrm{K}_{2} \mathrm{O} \cdot \mathrm{Al}_{2} \mathrm{O}_{3} \cdot 6 \mathrm{SiO}_{2}$.

\section{Response of Sugarcane in Puerto Rico to Potash Fertilizers and Foliar Analysis}

Tests of the response of sugarcane in Puerto Rico to the application of potash fertilizers generally have been limited to a few soils.

Sugarcane varieties B.H. 10 (12), P.O.J. 2878 and M. 275 responded significantly (3) in the field to an application of 400 pounds $\mathrm{K}_{2} \mathrm{O}$ per acre. The increase in yields for those varieties were 13,20 , and 19 percent, respectively. No significant yield response was obtained with the M. 28 variety. The amount of potash extracted by the sorghum from the soil sample of Coloso loam taken from that field was equivalent to 364 pounds of $\mathrm{K}_{2} \mathrm{O}$ per acre.

The weighted mean reduction in yield from the omission of potassium from the fertilizer in a group of soils in Puerto Rico was reported elsewhere to be 7 percent (6); of which 11 percent was the figure for the humid area. Soils which responded to potash fertilizers, i.e., Coloso silty clay, Vega Alta 
clay loam, and Mabí clay, all gave optimum yields when supplied with 150 pounds of $\mathrm{K}_{2} \mathrm{O}$ per acre. In the irrigated areas in the southern part of the Island there was actually a 3 -percent increase in yield when potassium was

TABLE 6.-Mean yields of cane per acre for 9 consecutive crops $^{1}$ of P.O.J. 2878 with different potash levels added to acid Vega Alta clay loam

\begin{tabular}{|c|c|c|c|c|}
\hline \multirow{2}{*}{ Crop No. } & \multirow{2}{*}{ Crop class } & \multicolumn{3}{|c|}{$\begin{array}{l}\text { Yield of cane when indicated quantity of } \mathrm{K}_{2} \mathrm{O} \text { was } \\
\text { used per acre per crop }\end{array}$} \\
\hline & & 90 pounds & 180 pounds & 270 pounds \\
\hline & & Tons & Tons & Tons \\
\hline 1 & First ratoon & $37.7^{2}$ & 38.5 & 38.3 \\
\hline 2 & Second ratoon & 42.3 & 45.3 & 45.1 \\
\hline 3 & Third ratoon & 36.1 & 39.1 & 37.6 \\
\hline 4 & Spring cane & 49.8 & 51.2 & 51.8 。 \\
\hline 5 & First ratoon & 47.9 & 50.8 & $50.0^{\circ}$ \\
\hline $6^{3}$ & Second ratoon & 57.1 & 61.4 & 60.9 \\
\hline $7^{3}$ & Third ratoon & 45.7 & 50.4 & 48.9 \\
\hline $8^{4}$ & Fourth ratoon & 43.2 & 46.2 & 45.7 \\
\hline $9^{4}$ & Fifth ratoon & 40.5 & 44.8 & 42.5 \\
\hline \multicolumn{2}{|l|}{ Mean for 9 crops $^{5}$. } & 43.2 & 46.2 & 45.7 \\
\hline
\end{tabular}

${ }^{1}$ Years 1943-52; a long-time experiment under the Soils Department, Agricultural Experiment Station, University of Puerto Rico, Río Piedras, P.R.

${ }^{2}$ Each value is the mean of 64 plots including 4 nitrogen levels: 103, 164, 225, 286 lbs. $\mathrm{N}$ per acre, and 2 phosphorus levels: 20 and 80 lbs. $\mathrm{P}_{2} \mathrm{O}_{5}$ per acre; and 8 replications.

${ }^{3}$ Responded to applications of potash in excess of $90 \mathrm{lbs} . \mathrm{K}_{2} \mathrm{O}$ per acre. Optimum fertilizer level was 103 lbs. N, 20 lbs. $\mathrm{P}_{2} \mathrm{O}_{5}$ and between 90 and $180 \mathrm{lbs} \mathrm{K}_{2} \mathrm{O}$ per acre, respecively.

4 Responded to applications of potash and nitrogen in excess of $90 \mathrm{lbs} . \mathrm{K}_{2} \mathrm{O}$ and 103 lbs. $\mathrm{N}$ per acre, respectively. Optimum fertilizer level was between 103 and $164 \mathrm{lbs}$. $\mathrm{N}, 20$ lbs. $\mathrm{P}_{2} \mathrm{O}_{5}$, and between 90 and $180 \mathrm{lbs} . \mathrm{K}_{2} \mathrm{O}$ per acre, respectively.

5 Significant response to potash for the mean of the 9 crops. Least significant difference between means was 1.25 and 1.31 at 1 - and 5 -percent points, respectively. No response to nitrogen and phosphorus. Optimum fertilizer level for the mean of the 9 crops was 103 lbs. N, 20 labs. $\mathrm{P}_{2} \mathrm{O}_{5}$, and between 90 and $180 \mathrm{lbs}$. $\mathrm{K}_{2} \mathrm{O}$ per acre, respectively.

omitted. The weighted mean reduction in yields from omission of nitrogen and phosphorus in that group of soils were 30 and 4 percent, respectively.

In a long-time field experiment what were essentially optimum sugarcane yields of P.O.J. 2878 were obtained in the first five consecutive crops, planted in acid Vega Alta clay loam of the humid area of Puerto Rico, with a minimum application of 90 pounds of $\mathrm{K}_{2} \mathrm{O}$ per acre per crop per year, 
as reported in table 6 . The sixth and other consecutive sugarcane crops up to the ninth inclusive, and the 9-crop mean yield, responded significantly to the application of potash in excess of 90 pounds $\mathrm{K}_{2} \mathrm{O}$ per acre.

No significant response to potash applications in excess of 90 pounds of $\mathrm{K}_{2} \mathrm{O}$ per acre was obtained in each of 10 consecutive crops of sugarcane planted under irrigation in Vayas clay, in the arid area of Puerto Rico. The first four crops were of B.H. 10 (2) and the others of P.O.J. 2878.

No significant yield response of M. 336 sugarcane was obtained with applications of $19,97,175$, and 253 , pounds of $\mathrm{K}_{2} \mathrm{O}$ per acre, respectively, in sand-lysimeter studies, as reported in table 7. No significant correlation

TABLE 7.-Mean yields ${ }^{1}$ of sugarcane and percentage of $K$ in the leaves at various stages of growth when different levels of potash were applied

\begin{tabular}{|c|c|c|c|c|c|c|c|}
\hline \multicolumn{3}{|c|}{ Treatment in pounds per acre } & \multirow{2}{*}{$\begin{array}{l}\text { Yield of cane } \\
\text { per acre }\end{array}$} & \multicolumn{4}{|c|}{ Potassium in leaves when sampled at- } \\
\hline $\mathrm{N}$ & $\mathrm{P}_{2} \mathrm{O}_{5}$ & $\mathrm{~K}_{2} \mathrm{O}$ & & 93 days & 122 days & 152 days & 182 days \\
\hline & & & Tons & Percent & Percent & Percent & Percent \\
\hline 240 & 175 & 19 & $13.32^{3}$ & $1.59^{3}$ & 1.22 & 2.69 & 1.13 \\
\hline 240 & 175 & 97 & 18.26 & 2.37 & 2.37 & 2.56 & 1.78 \\
\hline 240 & 175 & 175 & 18.19 & 2.78 & 1.98 & 2.21 & 1.12 \\
\hline 240 & 175 & 253 & 18.51 & 2.94 & 2.04 & 2.34 & 1.00 \\
\hline
\end{tabular}

${ }^{1}$ M.336 variety harvested at 9.5 months of age in irrigated sand lysimeters; minor elements were added. Unpublished data from experiment under Soils Department, Agricultural Experiment Station, University of Puerto Rico, Río Piedras, P. R.

${ }_{2}^{2}$ Least significant differences are 5.56 and 7.70 tons cane per acre at 5 - and 1 -percent points, respectively.

${ }^{3}$ Each value represents the mean of 4 replications.

was obtained either between the $\mathrm{K}$ content of the cane leaves at about 3 , 4,5 , and 6 months of age, respectively, and the yields of tons cane per acre or tons sugar per acre obtained with the four different levels of potash applied.

The range of $\mathrm{K}$ contents in the sugarcane leaves at a 3-month age varied from 1.59 to 2.94 percent, with the minimum and maximum applications of potash, respectively. Values below 1.80 percent $\mathrm{K}$ in 3 -month leaf samples of sugarcane tend to indicate deficiency of this element for optimum yields (6) in Puerto Rico.

\section{DISCUSSION}

Orthoclase and muscovite, both primary minerals of the feldspar and mica group, respectively, were not generally found in the soils of Puerto Rico studied. The active tropical weathering process has transformed these potash minerals into other combinations difficult to identify. It is thought 
that the potassium may be attached to the orthoclase feldspars, a group of sodium- and calcium-bearing minerals generally found in these soils.

The soils of Puerto Rico contain total potash in amounts varying from 200 to 18,200 pounds of $\mathrm{K}_{2} \mathrm{O}$ per acre, as reported in this paper. The available potash content extracted with 1-percent citric acid varied from 60 to 1,920 pounds of $\mathrm{K}_{2} \mathrm{O}$ per acre. The available potash content extracted in pot tests by dwarf sorghum, hegari variety, varied from 122 to 2,961 pounds of $\mathrm{K}_{2} \mathrm{O}$ per acre. In soils in which feldspars were present, the mean available potash extracted by the sorghum was about twice that extracted by the 1-percent citric acid and the values were close together in soils from which feldspars were absent.

Chemical methods are therefore not always reliable to determine the potash that plants absorb from the soil

\section{SUMMARY}

The potash-bearing minerals, the total potash content in some profiles, the available potash range, and the mean available potash extracted by 1-percent ctiric acid and by dwarf sorghum (hegari) in pot tests, are reported here for Puerto Rican soil groups.

In soils in which feldspars were present, the mean available potash extracted by the sorghum and by citric acid was equivalent to 747 and 376 pounds of $\mathrm{K}_{2} \mathrm{O}$ per acre, respectively. The sorghum extracted about twice as much potash.

In soils from which feldspars were absent, the mean available potash extracted by the sorghum and by citric acid was equivalent to 440 and 365 pounds of $\mathrm{K}_{2} \mathrm{O}$ per acre, respectively.

Chemical methods are therefore not always reliable to determine the potash that plants absorb from the soil.

Tests of the response of sugarcane in Puerto Rico to the application of potash fertilizers generally have been limited to a few soils.

Optimum sugarcane yields of P.O.J. 2878 were obtained in the first five consecutive crops, in an acid soil of Puerto Rico, with a minimum applicacation of 90 pounds of $\mathrm{K}_{2} \mathrm{O}$ per crop per year. The sixth and later sugarcane crops, and the 9-crop mean yield, responded significantly to the application of potash in excess of 90 pounds of $\mathrm{K}_{2} \mathrm{O}$ per acre.

No significant yield response was obtained with M. 336 grown in sand lysimeters with four increment levels varying from 19 to 253 pounds of $\mathrm{K}_{2} \mathrm{O}$ per acre, respectively. No significant correlation was obtained either between cane yields and the $\mathrm{K}$ contents of the cane leaves at different stages of growth.

The 3-month cane leaves varied from 1.54 to 2.94 percent of $K$, with the minimum and maximum applications of potash, respectively. 


\section{RESUMEN}

Se informan en este trabajo distintos aspectos sobre: los minerales potásicos, el contenido total de potasa de algunos perfiles, los valores mínimos y máximos de la potasa asimilable, el promedio de potasa asimilable extraído por un por ciento de ácido cítrico y por el sorgo enano, en pruebas con tiestos, todo en relación con algunos grupos de suelos de Puerto Rico.

En aquellos suelos en que se encuentran los feldespatos, el promedio de potasa asimilable, extraído por el sorgo y el ácido cítrico, fué 747 y 376 libras de $\mathrm{K}_{2} \mathrm{O}$ por acre, respectivamente. El sorgo extrajo el doble de potasa.

En los suelos sin feldespatos, el promedio de potasa asimilable extraído por el sorgo y por el ácido cítrico, fué 440 y 365 libras de $\mathrm{K}_{2} \mathrm{O}$ por acre, respectivamente.

Se concluye, que los métodos químicos no siempre resultan confiables para determinar con exactitud la cantidad de potasa que las plantas absorben del suelo.

La caña de azúcar generalmente ha respondido poco a las aplicaciones de los abonos potásicos en Puerto Rico.

Los mayores rendimientos de la variedad P.O.J. 2878 se obtuvieron en las primeras cinco cosechas consecutivas en un suelo ácido de Puerto Rico, con una aplicación mínima de 90 libras de $\mathrm{K}_{2} \mathrm{O}$ por cosecha, por año. La sexta cosecha al igual que las otras tres seguidas, como también el promedio de las nueve cosechas, respondieron significativamente a la aplicación de potasa en exceso a 90 libras de $\mathrm{K}_{2} \mathrm{O}$ por acre.

No hubo resultados significativos en los lisímetros de arena con cuatro niveles de aumento, los cuales variaron desde 19 hasta 253 libras de $\mathrm{K}_{2} \mathrm{O}$ por acre, respectivamente. Tampoco, hubo correlación significativa entre los rendimientos de la caña y el contenido de potasa de sus hojas, en las cuatro épocas distintas en las cuales se hicieron las observaciones.

A los 3 meses el contenido de potasa en las plantas de caña varió entre 1.54 y 2.94 por ciento de $\mathrm{K}$, respectivamente, en las aplicaciones mínimas y máximas de potasa.

\section{LITERATURE CITED}

1. Bonnet, J. A., The nature of laterization as revealed by chemical, physical and mineralogical studies of a lateritic soil profile from Puerto Rico. Soil Sci. 48 (1) 25-39 1939.

2. Bonnet, J. A., Chemical data of Puerto Rico soils; correlation of data for humid and arid areas; field response of crops to available phosphorus and potash in

- soils, Agr. Exp. Sta. Río Piedras, P. R., Res. Bul. 1, 53 p., Apr. 1941.

3. Capó, B. G., Cantidades asimilables de nutrimentos en los suelos de Puerto Rico; pp. 59-61; aumento en rendimiento de las cosechas debido a las aplicaciones de nutrimentos; pp. 61-4, Informe Bienal, Estación Experimental Agrícola, Río Piedras, P. R., 1938-40. 
4. Jeffries, C. D., Bonnet, J. A., and Abruna, F., The constituent minerals of some soils of Puerto Rico, J. Agr. Univ. P. R., 37 (2) 114-39., Apr. 1953.

5. Roberts, R. C. and party, Soil Survey of Puerto Rico, U.S.D.A. B. P. I., in coop. with Univ. of P. R., Agr. Expt. Sta., series 1936, No. 8, 503 pp., Jan. 1942.

6. Samuels, G., Bonnet, J. A., Landrau Jr., P., and Capó, B. G., Fertilizers for sugarcane, Sugar J., pp. 58, 60, 62, 82, May 1952.

7. Stewart, E. H. and N. J. Volk, Relation between potash in soils and that extracted by plants, Soil Sci. 61 125-9 1946.

8. Troug, E. and Jones, J. R., Fate of soluble potash applied to soils, Ind. and Eng. Chem. 30 882-5 1939.

9. Volk, G. W., The nature of potash fixation in soils, Soil Sci. 45 263-76 1938.

10. Winchell, A. N., Elements of optical mineralogy, An introduction to microscopic petrography, Part II, Description of minerals, p. 298, 4th edition, 551 pp., John Wiley \& Sons, Inc., New York, N. Y., 1951. 